\title{
Comparison of cellular toxicity caused by ambient ultrafine particles and engineered metal oxide nanoparticles
}

Senlin Lu*, Wenchao Zhang ${ }^{1}$, Rui Zhang ${ }^{1}$, Pinwei Liu' ${ }^{1}$, Qiangxiang Wang ${ }^{1}$, Yu Shang ${ }^{2}$, Minghong Wu ${ }^{1 *}$, Ken Donaldson ${ }^{3}$ and Qingyue Wang ${ }^{4^{*}}$

\begin{abstract}
Objective: The development of nanotechnology has spurred concerns about the health effects of exposure to nanoparticles (NPs) and ultrafine particles (UFPs). Toxicological data on NPs and UFPs may provide evidence to support the development of regulations to reduce the risk of particle exposure. We tried to provide fundamental data to determine differences in cytotoxicity induced by ambient UFPs and engineered metal oxide NPs ( $\mathrm{ZnO}, \mathrm{NiO}$, and $\left.\mathrm{CeO}_{2}\right)$.

Methods: UFPs were sampled by using of a nano micro-orifice uniform deposit impactor. Physicochemical characterization of the UFPs and nano metal oxide particles were studied by scanning electron microscopy and transmission electron microscopy. Cellular toxicity induced by the different particles was assessed by using of comprehensive approaches and compared after A549 cells were exposured to the particles.

Results: All of the measured particles could damage A549 cells at concentrations ranging from 25 to $200 \mu \mathrm{g} / \mathrm{mL}$. The lowest survival ratio and the highest lactate dehydrogenase level were caused by nano-ZnO particles, but the highest levels of intracellular reactive oxygen species (ROS) and percentages of apoptosis were observed in cells treated with the soluble fraction of ambient fine particles $\left(\mathrm{PM}_{1.8}\right)$ at $200 \mu \mathrm{g} / \mathrm{mL}$. Relatively high concentrations of anthropogenic metals, including $\mathrm{Zn}, \mathrm{Ni}$, Fe, and $\mathrm{Cu}$, may be responsible for the higher toxicity of fine ambient particles compared with the ambient coarse particles and UFPs. The selected heavy metals ( $\mathrm{Zn}, \mathrm{Ni}$, Fe, and $\mathrm{Cu}$ ) were found to be located in the perinuclear and cytoplasmic areas of A549 cells. The distribution pattern of metals from ambient particles showed that distributions of the metals in A549 cells were not uniform and followed the pattern $\mathrm{Cu}>\mathrm{Zn}>\mathrm{Fe}>\mathrm{Ni}$, suggesting that Cu was absorbed by A549 cells more easily than the other metals.
\end{abstract}

Conclusions: Metal nanoparticles oxides and UFPs at low concentration could damage to cells, but the manufactured metal oxide nanoparticles are not highly toxic to lung cells compared to environmental particles. The local concentration effect of heavy metals in A549 cells, as well as the induction of oxidative stress by the particles, may be responsible for the damage observed to the cells.

Keywords: Engineered nanoparticles, Ambient nanoparticles, Soluble components, Cytotoxicity

\footnotetext{
* Correspondence: senlinlv@staff.shu.edu.cn; mhwu@staff.shu.edu.cn; seiyo@mail.saitama-u.ac.jp

'School of environmental and chemical engineering, Shanghai University, No.333, Nanchen Rd, Shanghai 200444, China

${ }^{4}$ School of Science and Engineering, Saitama University, Saitama 338-8570, Japan

Full list of author information is available at the end of the article
} 


\section{Background}

Coarse particles are mostly deposited in the upper respiratory tract, whereas fine particles can be inhaled deep into the lung [1]. UFPs could directly injure the lung, inducing lung inflammation or translocation of inhaled particles from lung airspaces into the systemic circulation, eventually reaching other organs [2-5]. A number of studies have investigated the toxicity of ambient particles [6,7]. More recently, nanotoxicology has emerged as a new field for investigating the adverse biological outcomes of nanomaterials [2,8-10]. Because engineered nanoparticles (NPs) are now being produced in huge quantities, increased human and environmental exposure from various mechanisms, such as fugitive emission, accidental spills, and normal usage, is inevitable. Moreover, current environmental laws and occupational health guidelines are based on the nominal chemical composition of the material and seldom specify special standards for ultrafine or nanosized particles. Therefore, the potential occupational health and environmental effects of these nanosized particles are a public health concern [11].

Toxicologists have begun to focus on investigating the toxicological effects of exposure to NPs [10-14]. Because of the larger total surface area to volume ratio, small size, and other physicochemical properties (such as ability to absorb toxic metals and polycyclic aromatic hydrocarbons) of NPs, these particles can display toxicity profiles that are very different from those of larger materials of the same composition $[10,15]$, indeed, NPs have been shown to be more toxic than coarse and fine particles $[4,5]$. A number of studies have focused on the physicochemical characterization and toxicity of ambient particles [16], and a mechanism through which ambient particle induce toxicity (i.e., the oxidative stress theory) has been established [3-5]. Importantly, some of the procedures and assays that are generally used to assess the adverse biological effects of ambient PM could be applied for the study of engineered NPs [2]. For example, the ability to generate ROS and oxidative injury may provide a paradigm to compare the toxic potential of NPs [14]. However, studies comparing the toxicity of exposure to ambient UFPs and engineered NPs are limited.

In this study, we compared the toxicity of metal oxide NPs $\left(\mathrm{ZnO}, \mathrm{NiO}\right.$, and $\left.\mathrm{CeO}_{2}\right)$, which have been primarily used for industrial purposes, to that of ambient ultrafine, fine, and coarse particles sampled from the atmosphere in Shanghai. These results could provide fundamental data for the development of health risk assessments with respect to exposure to engineered NPs and airborne UFPs.

\section{Results}

Physicochemical characterization of size-resolved ambient particles

Mass concentrations of the size-resolved ambient particles

Mass levels of the airborne particles differed according to particle size (Figure 1). The average mass concentrations of coarse particles, fine particles, and UFPs were 95.34 \pm $24.92,77.41 \pm 15.6$, and $25.03 \pm 4.61 \mu \mathrm{g} / \mathrm{m}^{3}$, respectively.

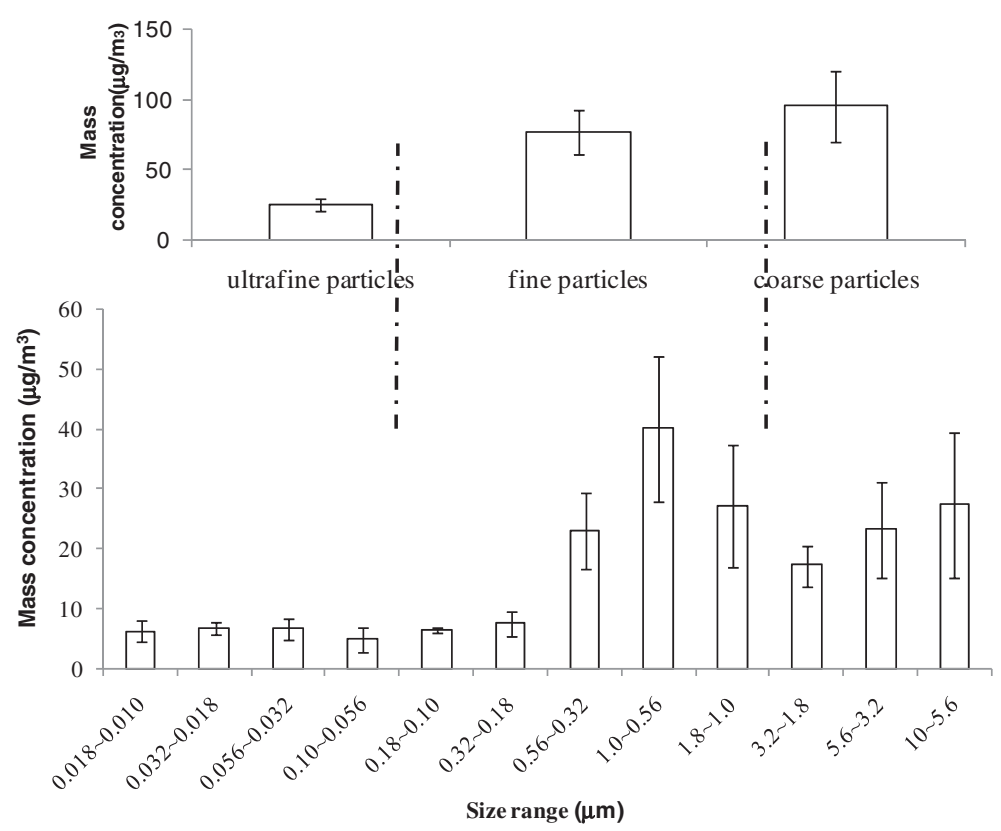

Figure 1 Mass concentration of ambient size-resolved particles collected at SDK site in winter in 2009. The sampling campaign was carried out from November 23 to December 5, 2009. The value of mass concentration of the size-resolved particles was expressed as means \pm standard deviations (SDs; $\mathrm{n}=5$ ). The error bars indicate standard deviation. 


\section{Chemical elements in the ambient particles}

Next, the mass concentrations of 20 elements, i.e., Si, P, $\mathrm{S}, \mathrm{Cl}, \mathrm{K}, \mathrm{Ca}, \mathrm{Ti}, \mathrm{V}, \mathrm{Cr}, \mathrm{Mn}, \mathrm{Fe}, \mathrm{Ni}, \mathrm{Cu}, \mathrm{Zn}, \mathrm{As}, \mathrm{Se}, \mathrm{Br}$, $\mathrm{Rb}, \mathrm{Sr}$, and $\mathrm{Pb}$, in Shanghai size-segregated particles were investigated by PIXE (See Additional file 1: Table S1). The chemical elemental analysis results showed that calcium $\left(2380.9 \mathrm{ng} / \mathrm{m}^{3}\right)$ was the most abundant crustal element in the coarse particles, while $\mathrm{Zn}$ $\left(490.48 \mathrm{ng} / \mathrm{m}^{3}\right)$ was the most abundant trace elements in the fine particles. $\mathrm{Si}\left(83.66 \mathrm{ng} / \mathrm{m}^{3}\right)$ was the most abundant element among the measured elements in the UFPs.

\section{Microscopic characterization of ambient particles}

SEM revealed that particles classified into the different size categories had visibly different attributes. Based on SEM morphological characteristics (Figure 2) and EDX spectra (data not shown), individual particle types in the sampling site atmosphere could be identified as fly ash $(\mathrm{Si}, \mathrm{Al}$, and $\mathrm{O}$ ), soot particles (carbon), regular mineral particles $(\mathrm{S}, \mathrm{O}, \mathrm{Cl}$, and $\mathrm{Na})$, and unidentified particles.

Microcharacterization of the nano- $\mathrm{ZnO},-\mathrm{NiO}$, and $-\mathrm{CeO}_{2}$ particles was performed using TEM. High-

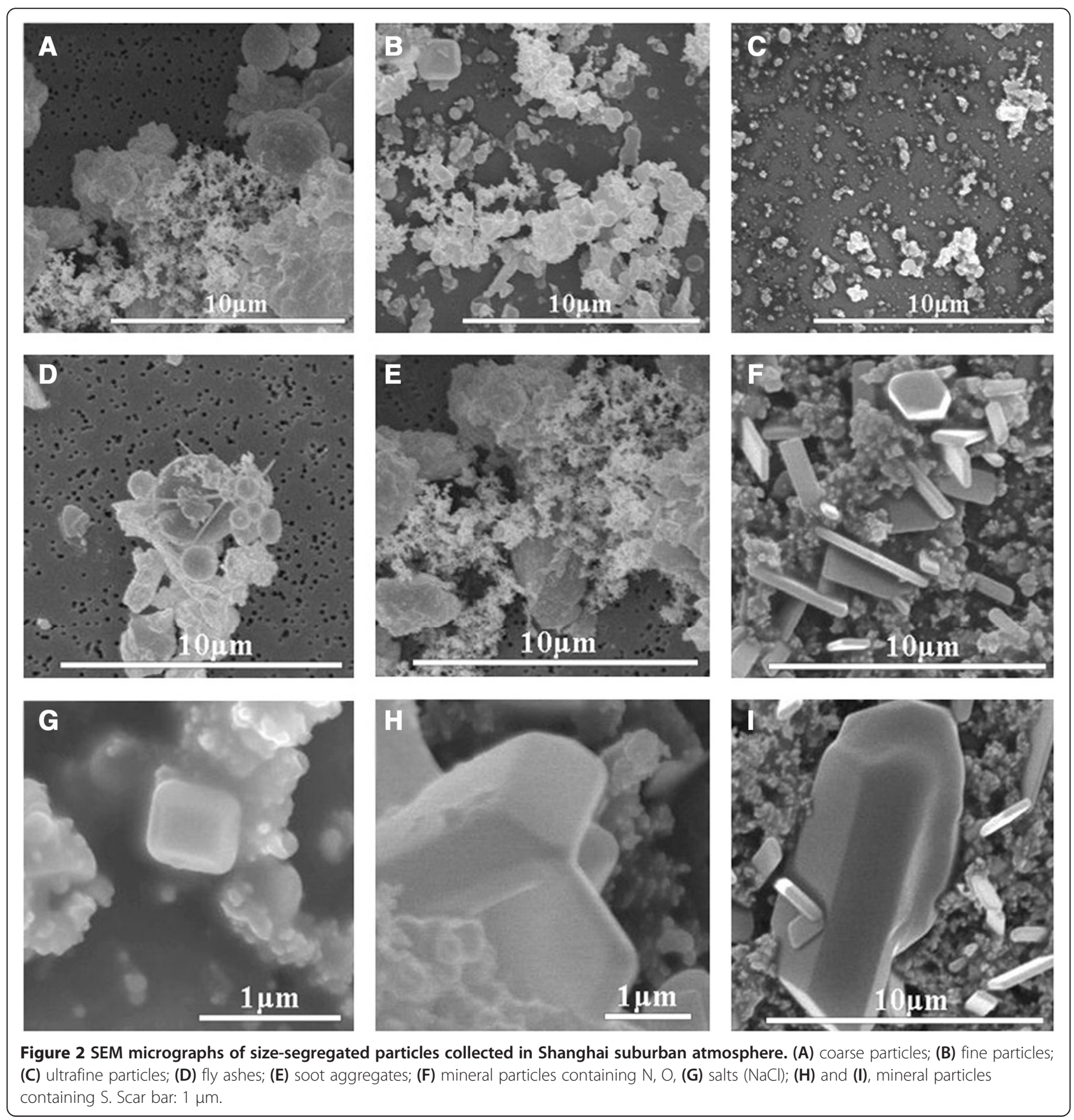


resolution TEM images revealed that nano- $\mathrm{ZnO}$ had a crystal structure, while nano- $\mathrm{NiO}$ and $-\mathrm{CeO}_{2}$ were in an amorphous state (Figure 3).

\section{MTT results}

In this experiment, due to the very low mass level of UFPs, the mass doses of the ambient UFPs were only 25 and $50 \mu \mathrm{g} / \mathrm{mL}$. With these concentrations of UFPs, MTT assays were used to evaluate the proliferation of A549 cells treated with ambient size-resolved particles and metal oxide NPs. The MTT assay results showed that cell viability decreased in response to exposure to size-resolved ambient particles and NPs at 25, 50,100, and $200 \mu \mathrm{g} / \mathrm{mL}$ (Figure 4). For example, exposure to the insoluble and soluble fractions of coarse particles at $25 \mu \mathrm{g} / \mathrm{mL}$ yielded cell viabilities of $0.97 \pm 0.02$ and $0.91 \pm$ 0.01 , respectively, cell viability was decreased to $0.7 \pm 0.09$ and $0.73 \pm 0.11$, respectively, when the concentration of particles was increased to $200 \mu \mathrm{g} / \mathrm{mL}$. Correspondingly, exposure to the insoluble and soluble fractions of fine particles decreased cell viabilities to $0.85 \pm 0.01$ and $0.92 \pm 0.06$ at $25 \mu \mathrm{g} / \mathrm{mL}$ and $0.6 \pm 0.03$ and $0.7 \pm 0.06$ at $200 \mu \mathrm{g} / \mathrm{mL}$, respectively. Treatment with insoluble and soluble fractions of ambient UFPs at 25 and $50 \mu \mathrm{g} / \mathrm{mL}$ also inhibited the proliferation of A549 cells $(0.94 \pm 0.01$ and $0.86 \pm 0.04$, respectively). Cell viability induced by NPs decreased in a concentration-dependent manner.

\section{LDH activity of the measured particles}

The LDH assay results showed that the different groups of particles induced varying levels of cytotoxicity. Compared with the control group, the LDH activity in cells treated with $\mathrm{PM}_{1.8}$ or NPs was significantly elevated (Figure $5, p<$ 0.05). Moreover, $\mathrm{PM}_{1.8}$ and NPs exhibited concentrationdependent effects on LDH activity. It was noteworthy that LDH activity induced by $\mathrm{PM}_{1.8}$ (soluble fraction) was stronger than that of $\mathrm{PM}_{1.8}$ (insoluble fraction).

\section{Intracellular ROS}

Similar to the results of cell viability and LDH activity, different particles exerted varying effects on intracellular ROS generation (Figure 6). Importantly, all of the particles tested in this study stimulated the induction of intracellular ROS. The highest fluorescent intensity $(0.098 \pm 0.013)$ was induced by $\mathrm{PM}_{1.8}$ (soluble fraction with $200 \mu \mathrm{g} / \mathrm{mL}$ ), while the lowest fluorescent intensity $(0.024 \pm 0.003)$ was induced by ambient UFPs (insoluble fraction with $50 \mu \mathrm{g} / \mathrm{mL}$ ).

\section{Induction of apoptosis in A549 cells exposure to the different particles}

Next, we analyzed the induction of apoptosis in A549 cells after a 12-h incubation with the different particle solutions. As shown in Figure 7, all the particle solutions could induce apoptosis in A549 cells. Interestingly, the soluble fractions of ambient particles induced significantly higher percentages of apoptotic cells compared the insoluble fractions and NP solutions.

\section{Distributions of metals in A549 cells}

Compared with the control, $\mathrm{Fe}, \mathrm{Ni}, \mathrm{Cu}$, and $\mathrm{Zn}$ exhibited differential distributions in A549 cells exposed to sizeresolved ambient particles (Figure 8). The fluorescence intensity of copper (Figure 8-h) in A549 cells was the highest, followed by $\mathrm{Zn}, \mathrm{Ni}$, and Fe. For the different sizes of ambient particles (coarse, fine, ultrafine), the four heavy metals exhibited the same trends, with $\mathrm{Cu}$ being most abundant (followed by Zn, Fe, and Ni; Figure 8-g, h, j-r). Interestingly, among NPs, the fluorescent intensity of nano- $\mathrm{ZnO}$ particles was higher than that of NiO NPs in A549 cells.

\section{Discussion}

Accumulating epidemiological and toxicological evidence has shown that there are important health risks associated

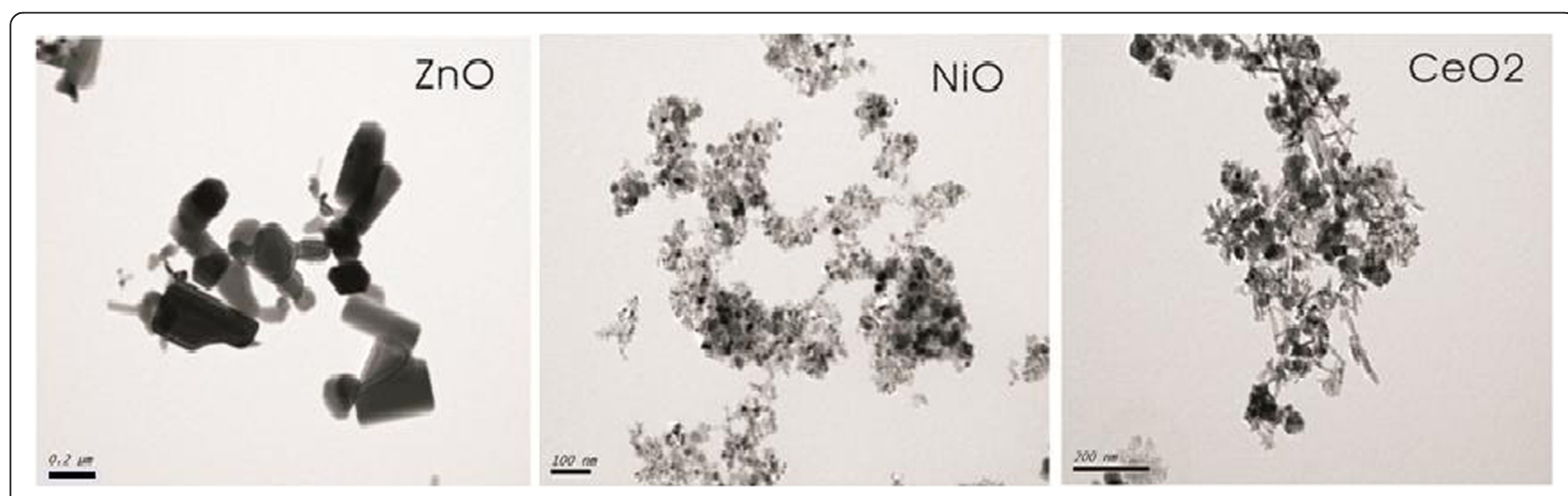

Figure 3 TEM morphological characterization of metal oxide nanoparticles. nano- $\mathrm{ZnO}$ had a crystal structure, while nano- $\mathrm{NiO}_{\text {and }}-\mathrm{CeO}_{2}$ were in an amorphous state. 


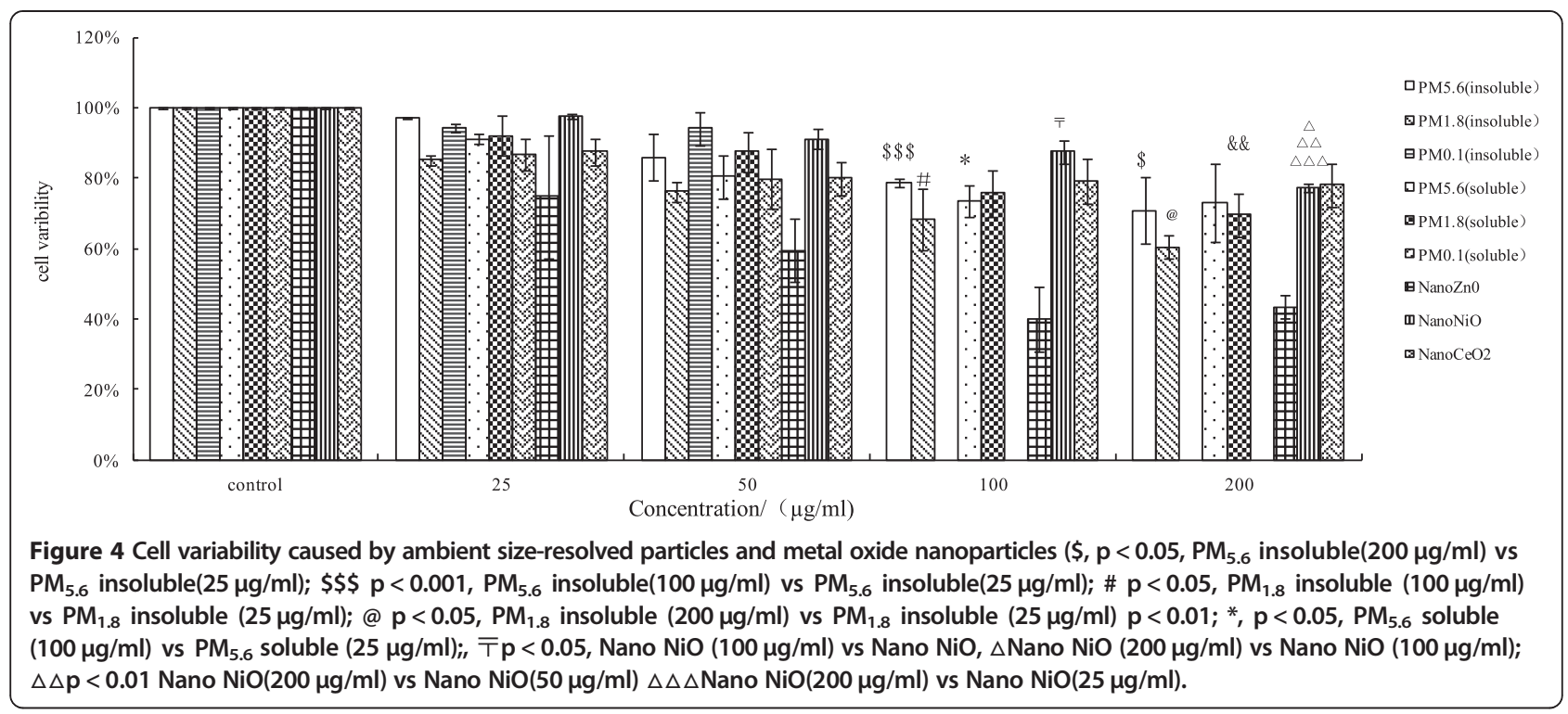

with exposure to engineered NPs and ambient UFPs $[9,15]$. Indeed, some UFPs can be found in the heart, lungs, blood vessels, and other organs after exposure to ambient air containing nanomaterials $[2,8,12,16]$. While a number of recent studies and reviews have described the potential hazards and toxicities of engineered NPs, it is difficult to obtain sufficient amounts of UFPs, and few studies have investigated this type of particle. Therefore, the purpose of this study was to assess the differences in cytotoxicity induced by ambient UFPs and engineered NPs.
Physicochemical characterization of ambient particles and NPs

Prior to toxicity studies, NPs and ambient particles should be appropriately characterized in repeated experiments in order to sufficiently characterize their toxic effects $[17,18]$. Therefore, we used a variety of methods, including SEM, TEM, and PIXE, to characterize the microscopic features and chemical compositions of the ambient particles and NPs. We found that Shanghai ambient particles consisted of fly ashes, soot aggregates, and mineral particles. Amorphous particles could be found in

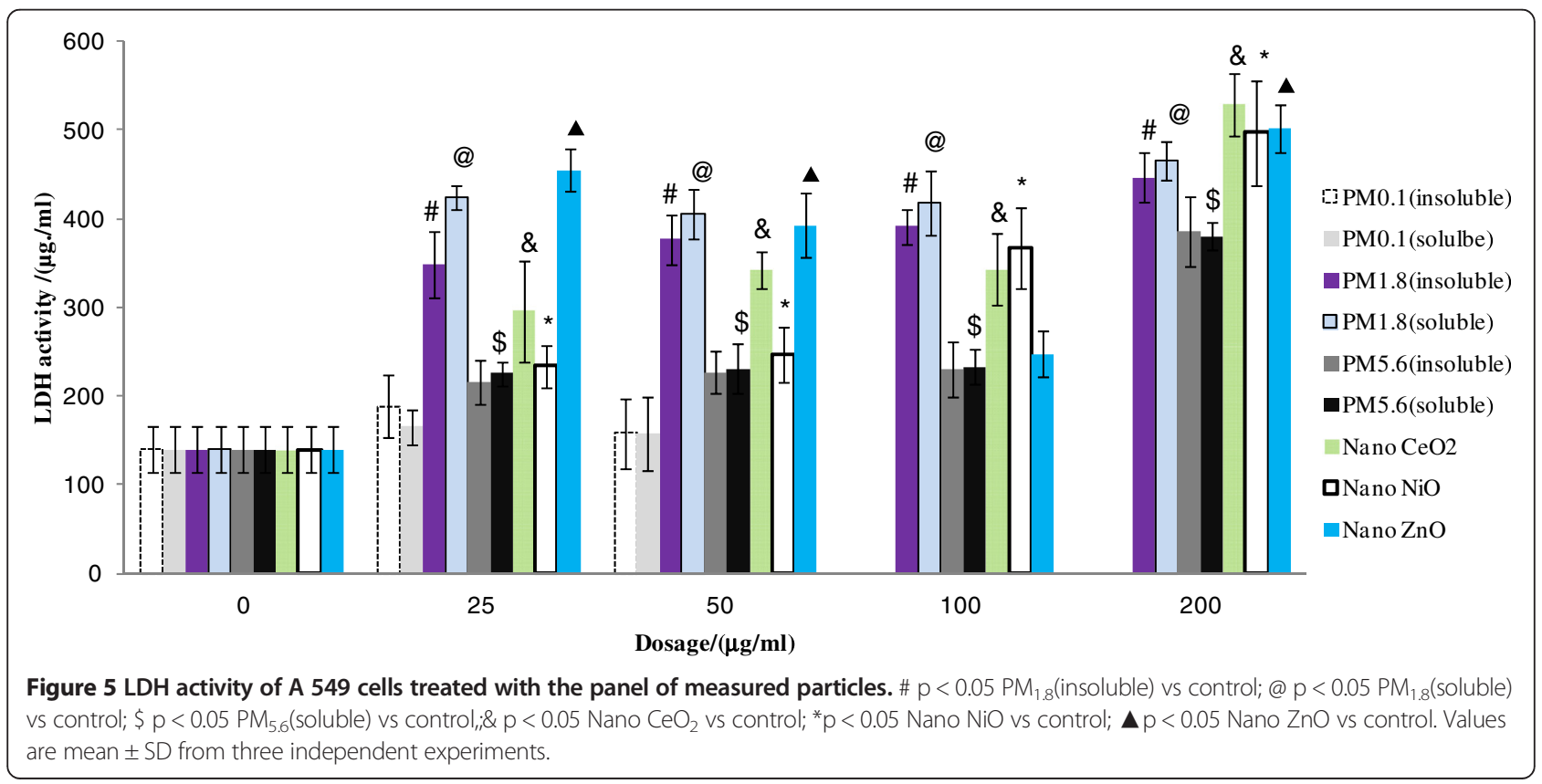



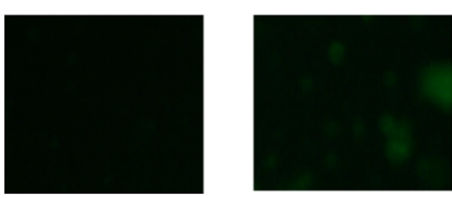

Control

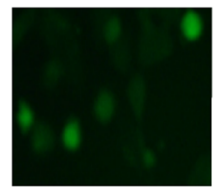

$\mathrm{PM}_{5.6}$ Insoluble

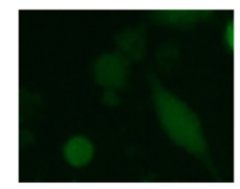

$\mathrm{PM}_{5.6}$ soluble
$\mathrm{PM}_{0.1}$ Insouble

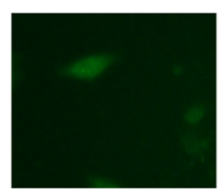

$\mathrm{PM}_{0.1}$ soluble

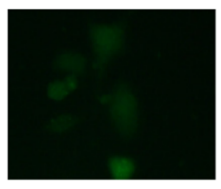

Nano $\mathrm{CeO}_{2}$

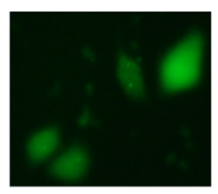

$\mathrm{PM}_{1.8}$ Insoluble

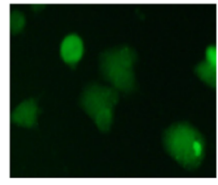

NanoNiO

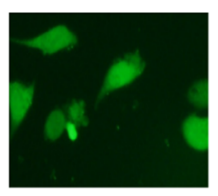

$\mathrm{PM}_{1.8}$ soluble

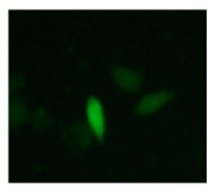

$\mathrm{NanoZnO}$

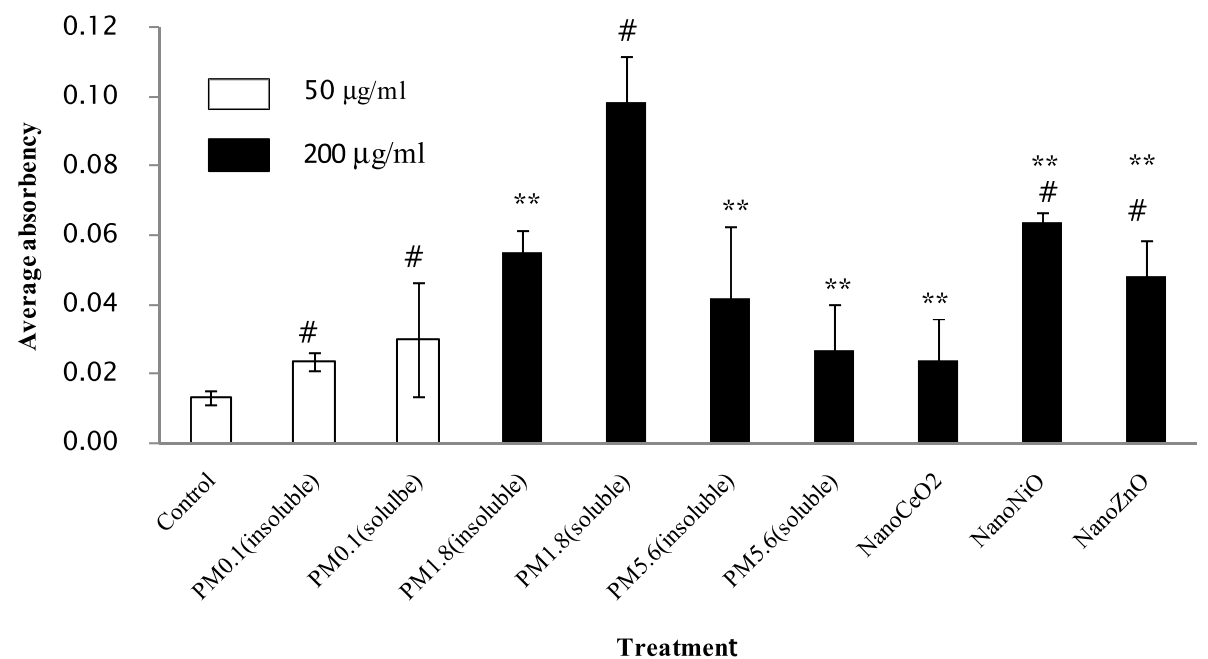

Figure 6 Intracellular ROS in A549 cells exposed to different components of particles, \# $\mathrm{p}<0.05$ as compared to Control; ${ }^{* *} \mathrm{p}<0.05$ as compared to $\mathrm{PM}_{\mathbf{1 . 8}}$ (soluble). Values are mean $\pm \mathrm{SD}$ from three independent experiments.

the UFP samples, while crystal particles were observed in the coarse/fine particle samples. EDX results (data not shown) demonstrated that the crystal particles consisted of $\mathrm{Ca}, \mathrm{S}, \mathrm{Na}$, and $\mathrm{O}$. Chemical analysis results (PIXE) revealed that crustal elements, i.e., Ca $\left(2830.91 \mathrm{ng} / \mathrm{m}^{3}\right)$, Fe $\left(972.17 \mathrm{ng} / \mathrm{m}^{3}\right), \mathrm{Si}\left(961.00 \mathrm{ng} / \mathrm{m}^{3}\right)$, and $\mathrm{Al}\left(414.01 \mathrm{ng} / \mathrm{m}^{3}\right)$, were mainly distributed in the coarse particle samples, while anthropogenic elements, including $\mathrm{Zn}$ (490.48 ng/ $\left.\mathrm{m}^{3}\right), \mathrm{Cu}\left(36.70 \mathrm{ng} / \mathrm{m}^{3}\right)$, and $\mathrm{Ni}\left(15.76 \mathrm{ng} / \mathrm{m}^{3}\right)$, were absorbed from fine particles. $\mathrm{Si}\left(83.66 \mathrm{ng} / \mathrm{m}^{3}\right)$ and $\mathrm{Al}$ $\left(83.52 \mathrm{ng} / \mathrm{m}^{3}\right)$ were the more abundant elements in the ambient UFPs, and the anthropogenic elements (such as $\mathrm{Zn}, \mathrm{Ni}$, and $\mathrm{Cu})$ were found at low levels $\left(<10 \mathrm{ng} / \mathrm{m}^{3}\right)$ in the UFP samples.

TEM results demonstrated that nano- $\mathrm{ZnO}(90-210 \mathrm{~nm})$ had a crystal structure, while nano-NiO (10-20 nm) and $-\mathrm{CeO}_{2}(20-32 \mathrm{~nm})$ were in the amorphous state. These physicochemical characterizations were conducive to the following comparison of the cellular toxicity of the measured particles.

\section{Cytotoxicity of ambient particles and NPs}

Our cell viability experiments (MTT) results demonstrated that all of the measured particles could damage A549 cells at different exposure concentrations $(25,50$, 100, and $200 \mu \mathrm{g} / \mathrm{mL}$ ). Lactate dehydrogenase (LDH) leakage assay results showed that cytoplasmic enzyme level released from the cells (after membrane damage) was in a dose-dependent manner. The lowest MTT ratio and highest $\mathrm{LDH}$ activity were observed for nano- $\mathrm{ZnO}$ particles (at the $50 \mu \mathrm{g} / \mathrm{mL}$ concentration), and the highest intracellular ROS intensity and apoptotic percentage were produced by the soluble fraction of ambient fine particles $\left(\mathrm{PM}_{1.8}\right)$ at $200 \mu \mathrm{g} / \mathrm{mL}$. ROS generation and oxidative stress produced by ambient particles and NPs are considered to be the main factors associated with particle toxicity [5]. Redox active metals, $\mathrm{Fe}, \mathrm{Cu}, \mathrm{Ni}$ through Fenton reaction to generate ROS and take adverse biological effects to cells, but for $\mathrm{Zn}$, one of nonredox active metals, its cellular toxicity could be explained that $\mathrm{Zn}$ ion released from $\mathrm{Zn}$ containing particles or $\mathrm{ZnO} \mathrm{NP}$, was responsible for 

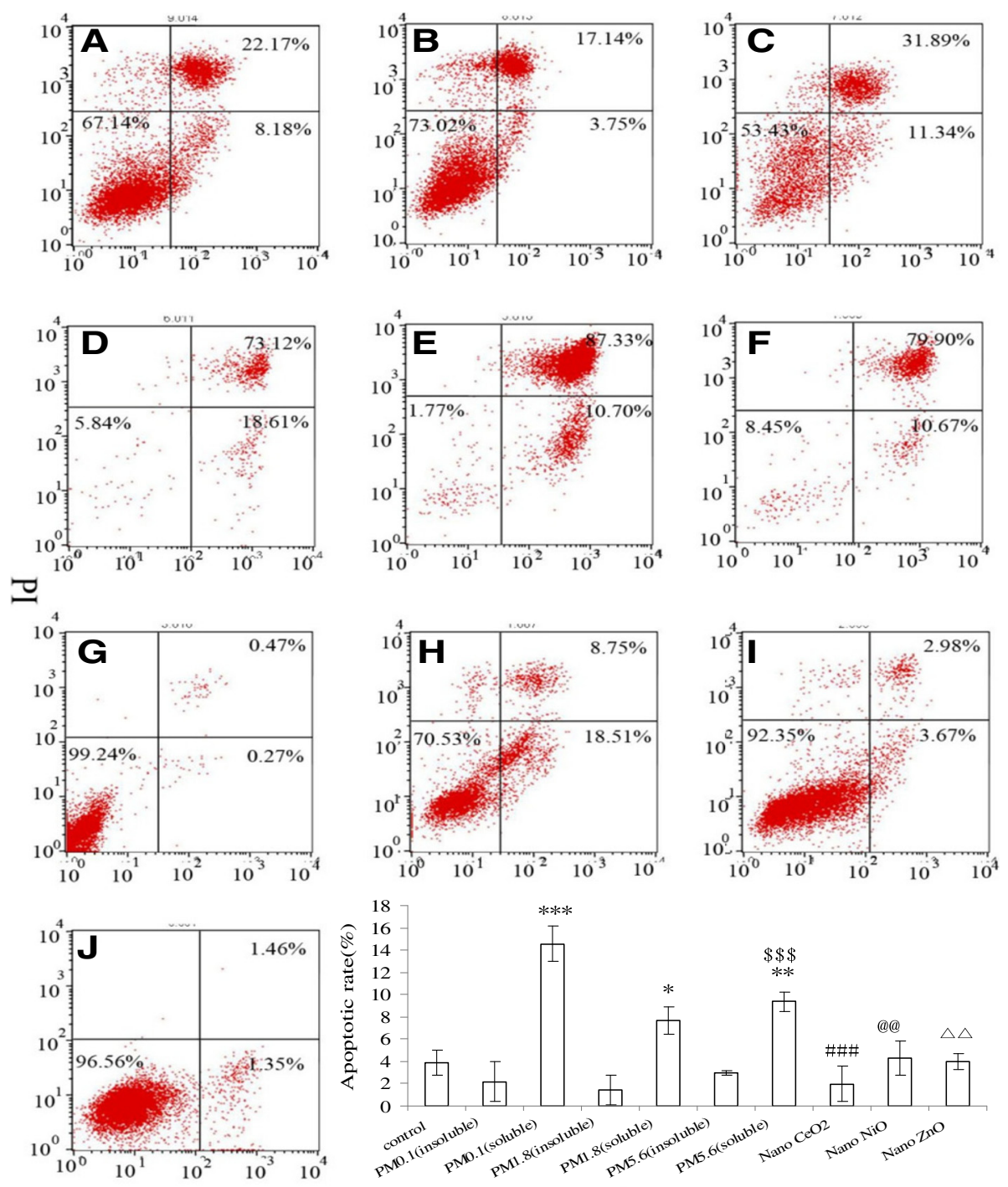

Annexin V FITC

Figure 7 Apoptosis of A549 cells after exposure to $200 \mu \mathrm{g} / \mathrm{ml}$ measured particles for 15 mins. A-ultrafine particles (insoluble fraction); B-fine particles(insoluble fraction); C-coarse particles(insoluble fraction); D-ultrafine particles (soluble fraction); E-fine particles (soluble fraction); F-Coarse particles (soluble fraction); G-Nano $\mathrm{CeO} 2 ; \mathbf{H}-\mathrm{NiO}$; $\mathbf{I}-\mathrm{ZnO}$; J-control. The data was expressed as the mean $\pm \mathrm{SD}$ of three independent experiments. ${ }^{*} p<0.05$ PM1.8(soluble) vs control; ${ }^{* *} p<0.01$ PM5.6(soluble) vs control; ${ }^{* * *} p<0.001$ PM0.1 (soluble) vs control; $\$ \$ p<0.001$ PM0.1 (insoluble) vs PM5.6(soluble); \#\#\# p < 0.001 PM1.8 (soluble) vs Nano CeO; @@ p<0.01 PM5.6(soluble)vs NiO; $\Delta \Delta p<0.01$ PM5.6(soluble)vs ZnO.

inducing inflammatory responses [19]. Deng et al. [20] also argued that the high toxicity of nano- $\mathrm{ZnO}$ could be explained by the mass level of $\mathrm{Zn}^{2+}$ in the solution. Our previous results revealed that the intensity of ROS generation by metal oxide NPs (nano- $\mathrm{NiO}$ and $-\mathrm{ZnO}$ ) positively correlated with the cellular toxicity induced by the two particles; however, nano- $\mathrm{CeO}_{2}$ particles could also produce high levels of free radicals, its cellular toxicity was weak [14], suggesting that cellular toxicity induced by NPs was associated with both particle size and chemical composition or the types of metal ions dissolved in the particle solutions. The ROS generated by exposure to the different particles could result in various cell injuries, including membrane damage and apoptosis. Moreover, our flow cytometry analysis also demonstrated that ambient fine particles and NPs damaged the cells. Notably, the highest apoptosis rate was observed in cells treated with UFPs, rather than ambient fine particles. This phenomenon could be explained by the direct interference effect of NPs $[18,21]$.

A number of studies have reported that NPs could translocate across the alveolar epithelial barrier and distribute into subcellular areas. SR-based techniques have been developed as a powerful technique to map the distribution of certain chemical elements in a single cell at high spatial resolution due to the extremely short wavelength 


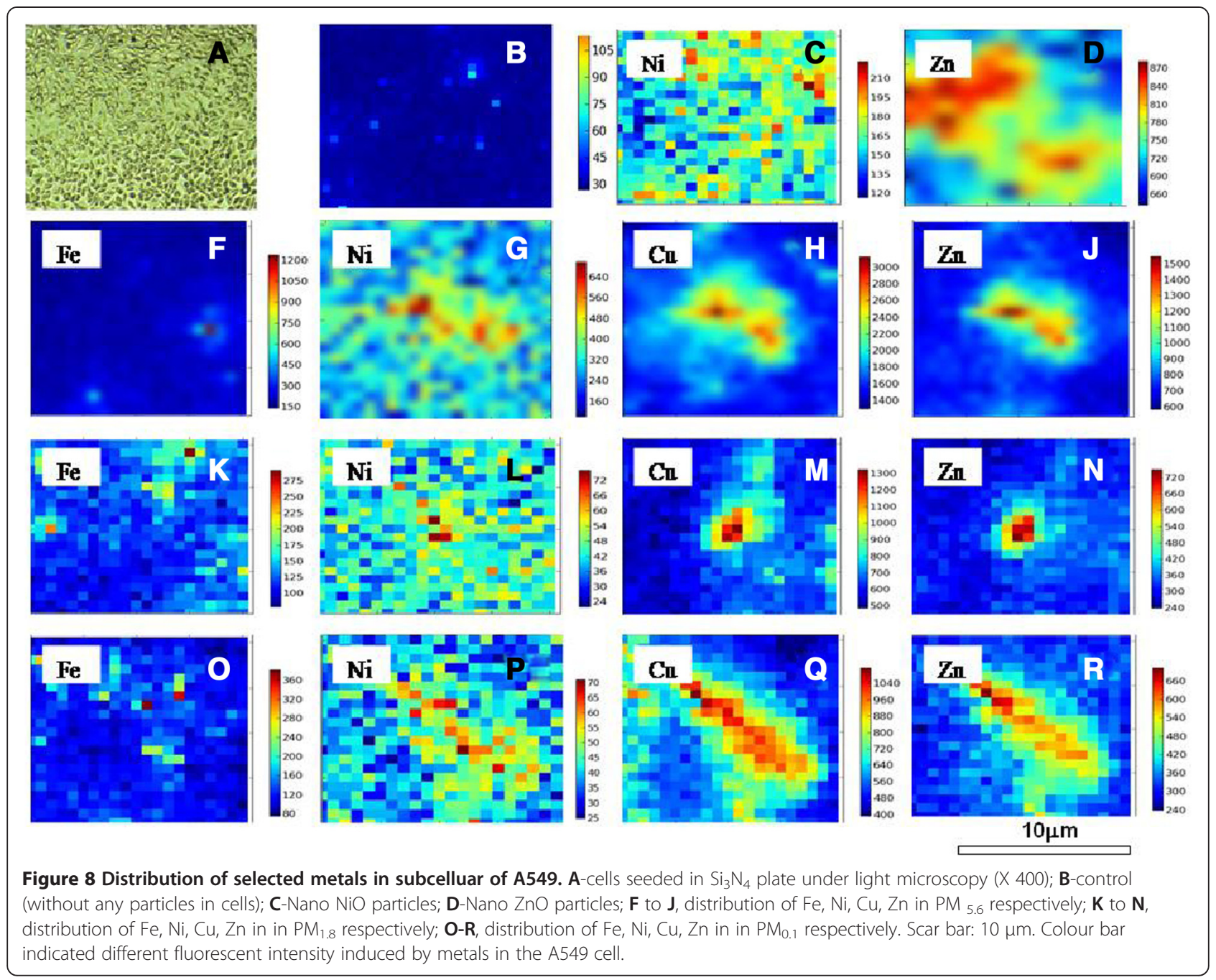

of X-rays [22]. In this study, we explored the subcellular localization of selected metals with this element-sensitive, nanometer-scale resolution imaging approach to further illustrate the detailed subcellular distribution patterns of ambient particles and NPs. In the untreated cells, the metals were not distinguished from the background in most areas of the cell; however, in cells treated with NPs and ambient particles, the selected metals $(\mathrm{Cu}, \mathrm{Fe}, \mathrm{Ni}$, and $\mathrm{Zn})$ could be observed. Generally speaking, the distributions of the metals in A549 cells were not uniform, and the fluorescent intensity of the selected metals in the ambient particles followed the pattern $\mathrm{Cu}>\mathrm{Zn}>\mathrm{Fe}>\mathrm{Ni}$, suggesting that $\mathrm{Cu}$ was absorbed more easily than the other metals. We noticed that the metals were concentrated in the perinuclear and cytoplasmic areas of the cell, consistent with the conclusions reported by Chen et al. [22], who found that quantum dot NPs were concentrated in the perinuclear and marginal areas of HeLa cells. This local concentration effect of the selected metals could be responsible for the observed higher cytotoxicity of ambient fine particles than of coarse particles, i.e., the high mass concentrations of $\mathrm{Cu}, \mathrm{Zn}, \mathrm{Fe}$, and $\mathrm{Ni}$ in the ambient fine particles could translocate across the alveolar epithelial barrier and distribute in subcellular areas, causing direct functional loss of these organelles. Thus, we hypothesize that this local concentration effect and the oxidative stress theory are the primary factors contributing to the effects of ambient particles and NPs on cell damage in A549 cells. Further studies are required to investigate this possibility.

\section{Conclusions}

Our results demonstrated that all of the measured particles could damage A549 cells at different exposure concentrations $(25,50,100$, and $200 \mu \mathrm{g} / \mathrm{mL})$. At the $50 \mu \mathrm{g} / \mathrm{mL}$ concentration, the lowest MTT ratio and highest LDH activity were observed for nano- $\mathrm{ZnO}$ particles. The highest intracellular ROS intensity and apoptotic percentage were produced by the soluble fraction of ambient fine particles $\left(\mathrm{PM}_{1.8}\right)$ at $200 \mu \mathrm{g} / \mathrm{mL}$. The relatively high mass concentration of anthropogenic metals, including $\mathrm{Zn}, \mathrm{Ni}, \mathrm{Fe}$, and 
$\mathrm{Cu}$, may be responsible for the higher toxicity of fine ambient particles compared with the ambient coarse particles and UFPs.

The selected heavy metals were concentrated in the perinuclear area and cytoplasmic area of A549 cells, as shown using SR. The distribution patterns of metals in ambient particles followed the pattern $\mathrm{Cu}>\mathrm{Zn}>\mathrm{Fe}>\mathrm{Ni}$, suggesting that $\mathrm{Cu}$ and $\mathrm{Zn}$ were more easily absorbed by the A549 cells. This local concentration may have important effects on cells, and oxidative stress theory may explain the damage induced in A549 cells by ambient particles and NPs. This hypothesis will need to be investigated further in future studies.

\section{Materials}

Sized-resolved ambient particles collected in Shanghai

The sampling site, located in Shidongkou (SDK), Shanghai $\left(31^{\circ} 27^{\prime} 06^{\prime \prime} ; 121^{\circ} 24^{\prime} 08^{\prime \prime}\right)$, was $2 \mathrm{~km}$ from Shidongkou power plant station. The sampling campaign was initiated on November 23, 2009 and was completed on December 5, 2009. A nano-MOUDI 125B sampler (MSP Co., Minneapolis, MN, USA) was installed on the fourth floor (about $10 \mathrm{~m}$ above ground) of the Shanghai Shengqiao Middle School building. A MOUDI sampler equipped with polycarbonate filters ( $47 \mu \mathrm{m}$ in diameter) was employed to collect size-resolved ambient particles. The MOUDI 125B sampler effectively separated the PM into 13 fractions (at $50 \%$ efficiency), with the following equivalent cutoff diameters $(\mu \mathrm{m}): 18-10,10-5.6,5.6-3.2$, $3.2-1.8,1.8-1.0,1.0-0.56,0.56-0.32,0.32-0.18,0.18-0.1$, $0.1-0.056,0.056-0.032,0.032-0.018,0.018-0.010 \mu \mathrm{m}$. The flow rate of the MOUDI $125 \mathrm{~B}$ sampler was $10 \mathrm{~L} / \mathrm{min}$. PM samples were collected onto polycarbonate filters (Millipore, UK) with pore sizes of $0.6 \mu \mathrm{m}$. The sampling time was $48 \mathrm{~h}$. The filters were kept in a desiccator until use.

\section{Metal oxide NPs}

Three types of metal oxide $\mathrm{NPs}, \mathrm{CeO}_{2}, \mathrm{NiO}$, and $\mathrm{ZnO}$, were purchased from Nanamor Co., USA. The sizes of the engineered nano- $\mathrm{CeO}_{2},-\mathrm{NiO}$, and $-\mathrm{ZnO}$ particles were $20-32,10-20$, and $90-210 \mathrm{~nm}$, respectively.

\section{Methods}

Physicochemical characterization of ambient particles and NPs

Microscopic characterization of ambient particles and NPs

Ambient particles were observed using a scanning electron microscope (SEM; JSM-6700 F, Japan) as described by Lu et al. [23]. Briefly, SEM images were obtained on an SEM equipped with an energy-dispersive X-ray system (EDX) and a $\mathrm{Si}(\mathrm{Li})$ detector, which allows X-ray detection from elements higher than carbonate $(Z>6)$. Operation conditions were as follows: $20 \mathrm{keV}$ accelerating voltage and 600 pA beam current, with spectral acquisition times of $30-100 \mathrm{~s}$.

Microscopic characterization of NPs was observed using a transmission electron microscope (TEM). For TEM observations, NPs were dispersed in ethanol by sonication, and a droplet of ethanol was then removed using a pipette and placed on the TEM grid. After the grid dried at room temperature, the NPs were observed under a JEM-2010 F TEM (Japan). The TEM was operated at $200 \mathrm{kV}$, and high-resolution TEM images were acquired.

\section{Analysis of chemical elements}

Chemical elements of the size-resolved particles were analyzed using proton-induced X-ray emission analysis (PIXE), as previously described [24]. Briefly, the filtered samples were cut into strips (width $\times$ length $=6 \times$ $3 \mathrm{~mm}^{2}$ ) and aligned in parallel on a plastic frame. About $1 \mathrm{~mm}$ was left blank between each sample, and a blank of about $10 \mathrm{~mm}$ was left in front of the first sample; in this position, we placed a fluorescent paper in order to perform appropriate instrumental adjustments. The collected samples were analyzed by PIXE (General Ionex Corp., USA) at the Institute of Low Energy Nuclear Physics, Beijing Normal University. This PIXE analyzer has been verified to be reliable by international standard intercomparisons $[25,26]$. For each sample, concentrations of 20 elements were determined, including $\mathrm{Mg}, \mathrm{Si}$, $\mathrm{P}, \mathrm{S}, \mathrm{Cl}, \mathrm{K}, \mathrm{Ca}, \mathrm{Ti}, \mathrm{V}, \mathrm{Cr}, \mathrm{Mn}, \mathrm{Fe}, \mathrm{Ni}, \mathrm{Cu}, \mathrm{Zn}, \mathrm{As}, \mathrm{Se}, \mathrm{Br}$, and $\mathrm{Pb}$. One blank filter was also analyzed for corrections of multi-element concentrations.

The chemical elements of $\mathrm{CeO}_{2}, \mathrm{NiO}$, and $\mathrm{ZnO}$ particles in water were previously analyzed [14].

\section{Particle solution preparation}

The ambient particles were divided into three groups based on their size range: $\mathrm{PM}_{10-5.6}, \mathrm{PM}_{5.6-3.2}$, and $\mathrm{PM}_{3.2-1.8}$ were combined as coarse particles; $\mathrm{PM}_{1.0-0.56}, \mathrm{PM}_{0.56-0.32}$, $\mathrm{PM}_{0.32-0.18}$, and $\mathrm{PM}_{0.18-0.1}$ were combined as fine particles; and $\mathrm{PM}_{0.1-0.056}, \mathrm{PM}_{0.056-0.032}, \mathrm{PM}_{0.032-0.018}$, and $\mathrm{PM}_{0.018-0.01}$ were combined as UFPs.

Filters were immersed in $5 \mathrm{~mL}$ deionized water in Eppendorf tubes for $1 \mathrm{~h}$ and then sonicated $(300 \mathrm{~W}$, $30 \mathrm{kHz}$ ) for $30 \mathrm{~min}$. The filters were then removed from the tubes and allowed to air dry at room temperature. The mass dosage of the particle solution was determined by measuring the difference in filter weights before and after immersing in water. Soluble fractions of the particles were achieved as follows. The stock solution was centrifuged at $3000 \mathrm{rpm}$ for $30 \mathrm{~min}$, and the supernatant $(2 \mathrm{~mL})$ was then carefully removed as the soluble fraction. The remaining $3 \mathrm{~mL}$ was dried by condensation, and after the procedure, $3 \mathrm{~mL}$ of deionized water was added into the tube as the particle insoluble fraction. 
The particle stock solution was diluted to $25,50,100$, or $200 \mu \mathrm{g} / \mathrm{mL}$ for subsequent experiments.

Solutions of engineered NPs were prepared by the following procedure. First, $0.2 \mathrm{~g}$ NPs were dissolved into $100 \mathrm{~mL}$ sterile deionized water in a measuring flask and sonicated for $1 \mathrm{~h}$ at room temperature. The stable suspension of NPs was used immediately. The $200 \mu \mathrm{g} / \mathrm{mL}$ particle solution was diluted to 100,50 , and $25 \mu \mathrm{g} / \mathrm{mL}$ with sterile deionized water for cell exposure experiments.

\section{Cell culture}

The type II human alveolar epithelial cell line A549 was maintained in continuous culture in Dulbecco's modified Eagle's medium (DMEM) supplemented with $10 \%$ heatinactivated fetal bovine serum (FCS), $2 \mathrm{mM}$ glutamate, $100 \mathrm{IU} / \mathrm{mL}$ streptomycin, and $100 \mu \mathrm{g} / \mathrm{mL}$ penicillin. Cells grew to confluence at $37^{\circ} \mathrm{C}$ in a humidified atmosphere containing $5 \% \quad \mathrm{CO}_{2}$ and were washed with phosphate-buffered saline (PBS), followed by harvesting with trypsin-EDTA.

\section{MTT assay}

For analysis of cell proliferation, $1 \times 10^{3}$ to $1 \times 10^{4}$ cells were seeded in each well in 96-well culture plates and allowed to attach for $24 \mathrm{~h}$. The cells were then washed with D-Hank's three times and exposed to $100 \mu \mathrm{L}$ of the ambient particle (coarse/fine/ultrafine) solution or difference concentrations of NPs $(25,50,100$, and $200 \mu \mathrm{g} / \mathrm{mL})$ for $4 \mathrm{~h}$. Next, $10 \mu \mathrm{L}$ of $5 \mathrm{mg} / \mathrm{mL}$ MTT solution was added to the culture medium and incubated for $4 \mathrm{~h}$ at $37^{\circ} \mathrm{C}$. The MTT reaction was terminated by addition of $150 \mu \mathrm{L}$ of dimethyl sulfoxide (DMSO), and the absorbance at $490 \mathrm{~nm}$ was recorded. Cells were treated in triplicate, and the experiment was repeated three times.

\section{Lactate dehydrogenase (LDH) leakage assay}

Cytotoxicity was assessed by LDH release as described by An et al. [27]. Briefly, LDH enzyme activity was assayed by colorimetry at $440 \mathrm{~nm}$ using a Quant microplate spectrophotometer (BioTek Instruments, Winooski, VT, USA). LDH leakage assays were performed to measure the cytotoxicity of the measured particles according to the manufacturer's protocol. The LDH activity was determined with following formula: LDH activity $(\mathrm{U} / \mathrm{L})=[$ (sample OD - control OD)/(standard OD - blank OD)] $\times$ standard concentration $\times$ dilution factor $\times 1000$. All experiments were carried out in triplicate and repeated three times.

\section{Measurement of intracellular ROS}

The levels of intracellular ROS were determined by the change in fluorescence resulting from the oxidation of the fluorescent probe $2^{\prime}, 7^{\prime}$-dichlorofluorescein diacetate (DCFH-DA). Cells were seeded in 6-well plates at a density of $1 \times 10^{5}$ cells $/ \mathrm{mL}$ and grown to confluence in media containing $10 \%$ fetal bovine serum (FBS). After exposure to ambient UFPs ( $50 \mu \mathrm{g} / \mathrm{mL}$, the maximum dosage of the UFPs we can prepare), ambient coarse particles, ambient fine particles, or nano particles $(200 \mu \mathrm{g} / \mathrm{mL})$, cells were treated with $10 \mu \mathrm{M}$ DCFH-DA. The plates were incubated at $37^{\circ} \mathrm{C}$ for $30 \mathrm{~min}$ in the dark, and cells were then washed twice with warm D-Hank's solution and evaluated under a fluorescence microscope (Olympus BX-51, Japan). The intensity of fluorescence was analyzed by Image-pro plus 6.0 software. Serum-free culture was used as negative control.

\section{Annexin V-FITC/propidium iodide (PI) apoptosis assay}

The quantification of apoptosis induced by silica particles in A549 cells was measured by flow cytometry (FCM, Becton Dickinson, USA) with Annexin V-FITC/ PI double staining as described by Deng et al. [20]. Briefly, the cells were harvested after $12 \mathrm{~h}$ of exposure to ambient UFPs ( $50 \mu \mathrm{g} / \mathrm{mL})$, ambient coarse particles, ambient fine particles, or NPs $(200 \mu \mathrm{g} / \mathrm{mL})$; washed twice with cold PBS $(0.15 \mathrm{M}, \mathrm{pH}=7.2)$; and resuspended to $1 \times 10^{6}$ cells $/ \mathrm{mL}$ in binding buffer. Then, $100 \mu \mathrm{L}$ of cells was transferred to a $5-\mathrm{mL}$ culture tube, and $5 \mu \mathrm{L}$ of FITC-conjugated Annexin V (Annexin V-FITC) and $5 \mu \mathrm{L}$ PI were added at room temperature in the dark. After incubation for $15 \mathrm{~min}$ at room temperature in the dark, stained A549 cells were diluted by the same binding buffer and directly analyzed by fluorescence-activated cell sorting (FACS, FACSCalibur, BD Biosciences, USA) according to the manufacturer's instructions. At least 10,000 cells were collected and detected by flow cytometry, and the percentages of apoptotic cells were analyzed by FACS Diva 4.1 software.

\section{Distribution of selected metals in A549 cells}

For analysis of the distribution of selected metals in cells, we used the methods described by Carter et al. [28], with modifications. A drop of A549 cell solution containing $10 \%$ FCS was removed onto a sterilized $\mathrm{Si}_{3} \mathrm{~N}_{4}$ crystal plate (attached to the bottom of a 24-well plate) using of pipette, and $5 \mathrm{~mL}$ DMEM was added into the wells. The plate was then incubated in a humidified atmosphere containing $5 \% \mathrm{CO}_{2}$ at $37^{\circ} \mathrm{C}$ for $24 \mathrm{~h}$. After the $\mathrm{Si}_{3} \mathrm{~N}_{4}$ plate (with cells attached) was washed with D-Hank's three times, $5 \mu \mathrm{L}$ of the particle solution (ambient particles, NPs; $25 \mu \mathrm{g} / \mathrm{mL}$ ) was added into the wells. Then, the $\mathrm{Si}_{3} \mathrm{~N}_{4}$ plate was kept in the incubator for $4 \mathrm{~h}$. The plate was washed with D-Hank's, and the cells were fixed on the $\mathrm{Si}_{3} \mathrm{~N}_{4}$ with alcohol (95\%).

The distribution of metal in the cells was analyzed with SR- $\mu$ XRF on a beamline BL15U instrument at Shanghai Synchrotron Radiation Facility (Shanghai, China) (Qiu et al.) [29]. The energy of the storage ring was $3.5 \mathrm{GeV}$ and the beam current was $200-300 \mathrm{~mA}$. 
Continuous synchrotron X-rays were monochromatized by an $\mathrm{Si}$ (111) double crystal. A monochromatic X-ray beam with a photon energy of $10 \mathrm{keV}$ was used to excite the samples. The cross-section of the beam irradiating on the samples was adjusted to about $2 \times 2 \mu \mathrm{m}^{2}$. The sample was placed at a $45^{\circ}$ angle to the incident X-ray beam, and X-ray fluorescence was detected with a $50 \mathrm{~mm}^{2}$ silicon drift detector (Vortex, USA) oriented at a $90^{\circ}$ angle to the incident beam. A light microscope was coupled to a computer for sample viewing. The sample platform was moved by a motorized $x-y$ mapping stage. The distributions of selected metals $(\mathrm{Ni}, \mathrm{Fe}, \mathrm{Cu}$, and $\mathrm{Zn})$ in the cells were continuously scanned at a step of $2 \mu \mathrm{m}$ for both the $x$ and $y$ directions. Each spot was irradiated for $100 \mathrm{~s}$. The data were analyzed by Plot software, and the differential metal distribution map was exported.

\section{Statistical analysis}

The data for mass concentration of ambient particles was analyzed by Excel and expressed as means \pm standard deviations (SDs; $n=5)$. The MTT assays, LDH assays, and intracellular ROS data were analyzed using SPSS software version 13.0 (SPSS Inc., Chicago, IL, USA), and data were expressed as means \pm SDs. Statistical significance was determined by using one-way analysis of variance (ANOVA). Differences with $p$ values of less than 0.05 were considered significant.

\section{Supporting information}

More details on mass level of chemical elements in the size-resolved particles were listed in supplementary table.

\section{Additional file}

Additional file 1: Table S1. Chemical elements in ultra/fine/coarse particles $\left(\mathrm{ng} / \mathrm{m}^{3}\right)$.

\section{Abbreviations \\ LDH: Lactate dehydrogenase; MTT: 3-(4,5-dimethyl-2-thiazolyl)-2,5-diphenyl-2- $\mathrm{H}$-tetrazolium bromide; PIXE: Proton-induced X-ray emission analysis; PI: Propidium iodide; NPs: Nanoparticles; ROS: Reactive oxygen species; SD: Standard deviation; SEM: Scanning electron microscopy; SR- $\mu \mathrm{XRF}$ : Synchrotron radiation $\mathrm{X}$-ray fluorescence micro-spectroscopy; TEM: Transmission electron microscopy; UFPs: Ultrafine particles.}

\section{Competing interests}

The authors declare that they have no competing interests.

\section{Authors' contributions}

All authors have made substantive contributions to this study. SL designed and drafted the manuscript. WZ conducted SEM, TEM and cytotoxicity experiments. RZ sampled ambient particles and analysed chemical elements. PL and QW drafted figures and carried out parts of data analysis. YS provided SR experiment. MW assisted with data analysis. KD conceptualized and substantively participated in the design. QW contributed to the drafting of the manuscript. All authors read and approved the final manuscript.

\section{Acknowledgements}

We acknowledge the support from the Natural Science Foundation of China (NSFC), and the Program for Innovative Research Team in the University, and thank Dr. Rodger Duffin and Dr. Craig Poland for their assistance.

\section{Sources of funding}

This research was supported by the NSFC (Grant Nos. 41273127, 21477073 and 10775094), and the Program for Innovative Research Team in the University (No. IRT13078).

\section{Author details}

${ }^{1}$ School of environmental and chemical engineering, Shanghai University, No.333, Nanchen Rd, Shanghai 200444, China. Institute for Environmental pollution and health, Shanghai University, Shanghai 200444, China.

${ }^{3}$ University of Edinburgh, Edinburgh, UK. ${ }^{4}$ School of Science and Engineering, Saitama University, Saitama 338-8570, Japan.

Received: 28 November 2014 Accepted: 16 February 2015

Published online: 19 March 2015

\section{References}

1. Kleinstreuer C, Zhang Z, Li Z. Modeling airflow and particle transport/deposition in pulmonary airways. Respir Physiol Neurobiol. 2008;163(1-3):128-38.

2. Xia T, Kovochich M, Brant J, Hotze M, Sempf J, Oberley T, et al. Comparison of the abilities of ambient and manufactured nanoparticles to induce cellular toxicity according to an oxidative stress paradigm. Nano Lett. 2006;6(8):1794-807.

3. Donaldson K, Beswick PH, Gilmour PS. Free radical activity associated with the surface of particles: a unifying factor in determining biological activity? Toxicol Lett. 1996;88:293-8.

4. Donaldson K, Brown DM, Mitchell C, Dineva M, Beswick PH, Gilmour P, et al. Free radical activity of PM10: iron-mediated generation of hydroxyl radicals. Environ Health Perspect. 1997;105:1285-9.

5. Donaldson K, Tran L, Jimenez LA, Duffin R, Newby DE, Mills N, et al. Combustion-derived nanoparticles: a review of their toxicology following inhalation exposure. Part Fibre Toxicol. 2005;2:10. doi:10.1186/1743-89977-2-10.

6. Donaldson K, Li X, MacNee W. Ultrafine (Nanometer) particle mediated lung injury. J Aerosol Sci. 1998;29:553-60.

7. Donaldson K, Stone V, Borm P, Jimenez L, Gilmour P, Schins R, et al. Oxidative stress and calcium signaling in the adverse effects of environmental particles (PM10). Free Radic Biol Med. 2003;34(11):1369-82.

8. Oberdorster $G$, Oberdorster E, Oberdorster J. Nanotoxicology: an emerging discipline evolving from studies of ultrafine particles. Environ Health Perspect. 2009;1 13(7):823-39.

9. Yacobi N, Fazllolahi F, Kim Y, Sipos A, Borok Z, Kim K, et al. Nanomaterial interactions with and trafficking across the lung alveolar epithelial barrier: implications for health effects of air-pollution particles. Air Qual Atmos Health. 2011;4:65-78.

10. Cassee FR, Mills NL, Newby DE. Cardiovascular Effects $O$ Inhaled Ultrafine and Nano-Sized Particles. Hoboken, New Jersey: John Wiley\&Sons, INC; 2011.

11. Veranth J, Kaser E, Veranth M, Koch M, Yost G. Cytokine response of human lung cells (BEAS-2B) treated with micro-sized and nanoparticles of metal oxides compared to soil dusts. Part Fibre Toxicol. 2007. doi:10.1186/1743-8977-4-2.

12. Oberdörster G, Sharp Z, Atudorei V, Elder A, Gelein R, Kreyling W, et al. Translocation of inhaled ultrafine particles to the brain. Inhal Toxicol. 2004; 16(6-7):437-45.

13. Poland C, Duffin R, Kinloch I, Maynard A, Wallace W, Seaton A, et al. Carbon nanotubes introduced into the abdominal cavity of mice show asbestos-like pathogencity in a pilot study. Nat Nanotechnol. 2008:3:423-8.

14. Lu S, Duffin R, Poland C, Daly P, Murphy F, Drost E, et al. Efficacy of short-term in vitro assay for predicting the potential of a panel of metal oxide nanoparticles to cause lung inflammation. Environ Health Perspect. 2009;117:2,241-247.

15. Mills NL, Donaldson K, Hadoke PW, Boon NA, MacNee W, Cassee FR, et al. Adverse cardiovascular effects of air pollution. Nature. 2009;6:1,36-44.

16. Xia $T$, Kovochich $M$, Liong $M$, Meng $H$, Kabehie $S$, George $S$, et al. Polyethyleneimine coating enhances the cellular uptake of mesoporous silica nanoparticles and allows safe delivery of siRNA and DNA constructs. ACS Nano. 2009;3(10):3273-86. 
17. Balbus J, Maynard A, Colvin V, Castronova V, Daston G, Denison R, et al. Meeting report: hazard assessment for nanoparticles-report from an interdisciplinary workshop. Environ Health Perspect. 2007;115(11):1654-9.

18. Li Y, Sun L, Jin M, Du Z, Liu X, Guo C, et al. Size-dependent cytotoxicity of amorphous silica nanoparticles in human hepatoma HepG2 cells. Toxicol In Vitro. 2011;25:1343-52.

19. Vandebriel RJ, Jong D. A review of mammalian toxicity of $\mathrm{ZnO}$ nanoparticles. Nanotechnol Sci Appl. 2012;5:61-71.

20. Deng X, Luan $Q$, Chen W, Wang Y, Wu M, Zhang H, Jiao Z. Nanosized zinc oxide particles induce neural stem cell apoptosis. Nanotechnology. 2009:20. doi:10.1088/0957-4484/20/11/115101.

21. Trouliller B, Reliene R, Westbrook A, Solaimani P, Schiestl R. Titanium dioxide nanoparticles induce DNA damage and genetic instability in vivo in mice. Cancer Res. 2009;69:8784-98.

22. Chen N, He Y, Su Y, Li X, Huang Q, Wang H, et al. The cytotoxicity of cadmium-based quantum dots. Biomaterials. 2012;33:1238-44.

23. Lu S, Shao L, Wu M, Jiao Z. Mineralogical characterization of airborne individual particulates in Beijing PM10. J Environ Sci. 2006;18(1):90-5.

24. Lu S, Shao L, Wu M, Jiao Z, Chen X. Chemical elements and their source apportionment of PM10 in Beijing urban atmosphere. Environ Monit Assess. 2007:133:79-85.

25. Zhu G, Wang G. Investigation of the particulate derived from indigenous zinc smelting using PIXE analytical technique. Nucl InstrumMethods Phys Res B. 1998;136:966-9.

26. Zhu G, Wang G. International comparison of PIXE analysis results. Climate Environ Res. 2000;5(1):30-5.

27. An J, Yin L, Shang Y, Zhong Y, Zhang X, Wu M, et al. The combined effects of BDE47 and BaP on oxidatively generated DNA damage in L02 cells and the possible molecular mechanism. Mutat Res. 2011;721:192-8.

28. Carter E, Rayner B, Mcleod A, Wu L, Marshall C, Levina A, et al. Silicon nitride as a versatile growth substrate for microspectroscopic imaging and mapping of individual cells. Molecular Biosystems. 2010;6:1316-22.

29. Qiu J, Deng B, Yang Q, Yan F, Li A, Yu X. Internal elemental image by scanning $X$-ray fluorescence microtomography at the hard $X$-ray microprobe beamline of the SSRF: Preliminary experimental results. Nucl InstrumMethods Phys Res B. 2011;269:2662-6.

\section{Submit your next manuscript to BioMed Central and take full advantage of:}

- Convenient online submission

- Thorough peer review

- No space constraints or color figure charges

- Immediate publication on acceptance

- Inclusion in PubMed, CAS, Scopus and Google Scholar

- Research which is freely available for redistribution 